UDK: 342.8+351.86:314.15(497.5)“2019/2020"

Prethodno priopćenje

Primljeno 14. kolovoza 2020.

\title{
Sekuritizacija iregularnih migracija u kampanji za predsjedničke izbore u Republici Hrvatskoj 2019./2020.
}

\section{GORAN DŽIDIĆ}

mag. nov., doktorski kandidat na poslijediplomskom doktorskom studiju

Politologija na Fakultetu političkih znanosti Sveučilišta u Zagrebu

dzidic.goran@gmail.com

Nekoliko godina nakon vrhunca migracijske krize iz 2015. godine, ovaj oblik nevojne prijetnje postao je važan dio političke debate na nacionalnoj i nadnacionalnoj razini Europske unije. Republika Hrvatska, kao država koja je dio tzv. balkanskog pravca migracija, nije iznimka. Migracijska kriza iz 2015./2016. godine predstavljala je jedno od glavnih pitanja o kojem se raspravljalo tijekom kampanje za predsjedničke izbore 2019./2020. godine u Republici Hrvatskoj. U radu se kritičkom analizom diskursa istražuju stavovi predsjedničkih kandidata Zorana Milanovića i Kolinde Grabar-Kitarović vezani za sigurnosne izazove koje predstavljaju masovne migracije. Kao jedinice analize, u istraživanju su korištene izjave predsjedničkih kandidata prezentirane na tri televizijska sučeljavanja održana tijekom kampanje za predsjedničke izbore.

Ključne riječi: sekuritizacija, iregularne migracije, kritička analiza diskursa, predsjednički izbori, Republika Hrvatska, Europska unija 


\section{Uvod}

Kampanja za predsjedničke izbore 2019./2020. godine u Republici Hrvatskoj službeno je počela 5. prosinca 2019. godine. U prvom krugu predsjedničkih izbora natjecalo se 11 kandidata, a najviše glasova osvojili su Zoran Milanović ${ }^{1}, 29,55$ \% i Kolinda Grabar-Kitarović ${ }^{2}$, 26,65 \%. Navedeni su kandidati prošli u drugi krug izbora, a odlukom građana, peti predsjednik Republike Hrvatske postao je Zoran Milanović s osvojenih 52,67 \% glasova ${ }^{3}$. Ovlasti koje ima Predsjednik Republike Hrvatske u području obrane i nacionalne sigurnosti su različite. Svojim političkim utjecajem i položajem, unatoč određenim ograničenjima, može utjecati na dinamiku provođenja izvršne i zakonodavne vlasti te ima utjecaja u vođenju vanjske politike. Stoga, uz svjetonazorska pitanja, gospodarstvo, demografiju, korupciju, vanjsku i unutarnju politiku, iregularne migracije ${ }^{4}$ su bile jedna od važnijih tema o kojima se raspravljalo tijekom izborne kampanje.

Zbog kvalitetnije predodžbe o ovlastima Predsjednika RH, u Tablici 1 predstavljeni su rezultati analize kojom je obuhvaćeno 26 propisa Republike Hrvatske (Ustav RH, 15 zakona, Poslovnik Hrvatskog sabora, tri pravilnika i šest odluka) u kojima se spominju dužnosti Predsjednika. Analiza je pokazala kako Predsjednik Republike Hrvatske ima ukupno 71 samostalnu i 117 nesamostalnih ovlasti „vezanih uz prijedlog, suglasnost i supotpis neke osobe koja obnaša određenu dužnost ili tijela. Naravno, i u takvim slučajevima predsjednik samostalno odlučuje, pa može i ne prihvatiti prijedlog ili što je propisano “5.

Tablica 1: Ovlasti predsjednika u političkom sustavu Republike Hrvatske

\begin{tabular}{c|c|c|c} 
PROPIS & Vezane ovlasti & $\begin{array}{c}\text { Samostalne } \\
\text { ovlasti }\end{array}$ & Ukupno \\
\hline Ustav Republike Hrvatske & 29 & 24 & 53 \\
\hline Zakon o obrani & 53 & 10 & 63 \\
\hline Zakon o službi u OSRH & 13 & 10 & 23 \\
\hline Zakon o Obalnoj straži & 3 & - & 3 \\
\hline Zakon o odlikovanjima i priznanjima RH & - & 6 & 6 \\
\hline Odluke o medaljama & 2 & - & 2 \\
\hline Zakon o vanjskim poslovima & 11 & - & 11 \\
\hline Zakon o sigurnosno-obavještajnom sustavu RH & 6 & 9 & 15 \\
\hline Ostali propisi & - & 12 & 12 \\
\hline
\end{tabular}

Izvor: Večernji list (dostupno na poveznici: https://www.vecernji.hr/premium/kolika-je-stvarna-moc-vladara-pantovcakamilanovic-ima-cak-188-ovlasti-1379522)

1 Zoran Milanović bio je predsjednički kandidat lijevo orijentirane stranke SDP. Kao bivši premijer i bivši predsjednik SDP-a, Milanović je u utrku za mjesto predsjednika Republike Hrvatske ušao s iskustvom na poljima unutarnje i vanjske politike. Za kontekst istraživanja bitno je naglasiti kako je Milanović za vrijeme migracijske krize iz 2015./2016. godine kao premijer aktivno sudjelovao u rješavanju problema nekontroliranog priljeva migranata.

2 Kolinda Grabar-Kitarović u utrku za novi mandat krenula je kao kandidatkinja stranke HDZ. Nakon obnašanja dužnosti predsjednice Republike Hrvatske u trajanju od 5 godina, K. Grabar-Kitarović se kandidirala za novi mandat. Kao predsjednica RH, također je bila jedan od važnijih političkih aktera za vrijeme migracijske krize iz 2015. godine.

3 www.izbori.hr (2019) https://www.izbori.hr/pre2019/rezultati/1/ (pristupljeno: 7. 12. 2020.).

4 Prema Međunarodnoj organizaciji za migracije, pojam „iregularne migracije“ označava sve vrste kretanja ljudi koje izlaze iz okvira regulativnih normi.

5 www.večernji.hr (2020) https://www.vecernji.hr/premium/kolika-je-stvarna-moc-vladara-pantovcaka-milanovic-ima-cak-188ovlasti-1379522 (pristupljeno: 16. 2. 2020.) 
Uloga Predsjednika RH u kontekstu iregularnih migracija u posebnom je fokusu nakon migracijske krize iz 2015./2016. godine. Predsjednik je vrhovni zapovjednik Oružanih snaga uz čiju se suglasnost donosi različit spektar odluka vezanih za djelovanje oružanih snaga, koje između ostalog, od 2016. godine prema zakonu imaju „sigurnosne i humanitarne“ ovlasti u pružanju potpore pri zaštiti granice. Naime, samo nekoliko mjeseci nakon krize, usvojene su izmjene Zakona o nadzoru državne granice i dopune Zakona o obrani s ciljem osiguravanja kvalitetnijeg odgovora na humanitarne i sigurnosne izazove koje donose masovne migracije. ${ }^{6}$ Izmjene navedenih zakonskih akata izravno se tiču uloge Predsjednika države kao bitnog aktera u procesu sekuritizacije migracija. Primjerice, u Zakonu o nadzoru državne granice navodi se kako zbog „sigurnosnih i/ili humanitarnih razloga, Oružane snage Republike Hrvatske mogu pružiti potporu u zaštiti državne granice na način propisan zakonom kojim se uređuje obrana Republike Hrvatske (Zakon o nadzoru državne granice NN 83/13 (NN 27/16)). Dok se u Zakonuo obrani navodi kako „Oružane snage mogu pružiti potporu policiji u zaštiti državne granice u skladu sa zakonom kojim se uređuje nadzor granice, a odluku donosi Vlada, na prijedlog ministra obrane i uz prethodnu suglasnost Predsjednika Republike." (Zakon o obrani NN 73/13 (NN 30/18)).

Iregularne migracije u kontekstu sigurnosnih izazova predstavljale su jednu od važnijih tema o kojima se raspravljalo tijekom izborne kampanje za izbor predsjednika Republike Hrvatske. Metodom kritičke analize diskursa istražit će se jezik kojim su se koristili predsjednički kandidati Zoran Milanović i Kolinda Grabar-Kitarović, a koji je vezan za stavove o problemu migracija. Istraživanje obuhvaća razdoblje od 5. prosinca 2019. do 5. siječnja 2020. godine, odnosno od službenog početka predsjedničke kampanje, do dana izborne šutnje prije drugog kruga predsjedničkih izbora. Analiziraju se sve izjave navedenih kandidata na televizijskim sučeljavanjima koje su prezentirane u kontekstu problema masovnih migracija. Stoga ovo istraživanje ima za cilj ponuditi odgovore na sljedeća istraživačka pitanja:

1. Jesu li predsjednički kandidati u televizijskim sučeljavanjima predstavljali migracije kao sigurnosnu prijetnju?

2. Koje su razlike u stavovima predsjedničkih kandidata vezanim za sigurnosne izazove koje donose masovne migracije?

\section{2. „Balkanski pravac migracija“ tijekom migracijske krize 2015./2016. godine}

Nakon završetka hladnog rata, sigurnosnom diskursu u Europi dodano je nekoliko novih elemenata uključujući okoliš, migracije, etničke sukobe, organizirani kriminal i terorizam (Buzan, Wæver, 2003). Sigurnosni diskurs u Europi se do danas nije značajno promijenio, a u prilog tome idu društvena i politička zbivanja vezana za migracijsku krizu iz 2015./2016. godine. Važno je istaknuti kako se diskurs uvijek javlja u okvirima određenoga društvenog konteksta. Ristić (2015) navodi kako diskurs predstavlja materijalizirani sadržaj iskaza kojeg društveni akteri razmjenjuju u društvenim kontekstima koji nose određeno značenje. Stoga je bitno objasniti pozadinu, odnosno društveni kontekst, događaja koji su generirali temu masovnih migracija u kontekstu sigurnosti, a koja je značajno bila zastupljena u kampanji za predsjedničke izbore u Hrvatskoj 2019./2020. godine.

Različiti push i pull faktori, kao što su ratovi i ekonomska nestabilnost, 2015. godine su uzrokovali velika migracijska kretanja iz smjera nefunkcionalnih država Bliskog istoka i sjeverne Afrike prema EU. Europska unija se tako suočila s migracijskom krizom koja je kulminirala u rujnu 2015. godine i trajala do ožujka 2016. godine, kada je potpisana Izjava EU-a i Turske s ciljem zaustavljanja masovnih

6 www.jutarnji.hr (2016) https://www.jutarnji.hr/vijesti/hrvatska/na-sjednici-vlade-usvojen-novi-zakon-vojska-moze-na-granicumerkel-odusevila-premijera-sastanak-je-bio-sjajan/27514/ (pristupljeno: 7. 1. 2020.) 
migracija prema EU-u. Problem nekontroliranog priljeva migranata često je rješavan na nacionalnoj razini, umjesto na razini EU-a. Neke su članice EU-a sekuritizirale migracije, zatvorile granice i preusmjerile migracijske tokove, zbog čega su odnosi između nekih država članica EU-a značajno narušeni.

Ekonomski najrazvijenije članice EU-a kao što su Njemačka, Velika Britanija i Italija, upravljale su migracijama iz 2015. godine prema vlastitim ekonomskim potrebama, ostavljajući države članice na rubnim dijelovima EU-a pred velikim izazovima koje donosi nekontrolirani priljev migranata, bez obzira na njihove kapacitete i resurse. Nejednakom distribucijom odgovornosti na površinu su izašle nejednakosti i duboke nesuglasice među zemljama članicama, a politički akteri unutar pojedinih zemalja članica navedenu su situaciju iskoristili te su populističkim diskursom mobilizirali javnost i predstavili izvanredne mjere koje nisu u skladu s pravnom stečevinom EU-a. Jačanje populističkih, nacionalističkih, euroskeptičnih stranaka i pokreta u zemljama EU-a, promjene u politikama azila i migracija, antiimigrantski diskurs političkih aktera, donošenje novih antiterorističkih zakona, pojačane granične kontrole i postavljanje fizičkih barijera na granicama zemalja EU-a postavile su problem masovnih migracija u središte političkih zbivanja na nacionalnoj i nadnacionalnoj razini EU-a. Istraživanje Eurobarometra iz 2019. godine pokazalo je kako građani EU-a i dalje smatraju migracije najvažnijim problemom s kojim se EU trenutno suočava. ${ }^{7}$

Slika 1: Anketa Eurobarometra (jesen 2019. godine) - Što mislite koji je trenutno najveći problem s kojim se EU suočava?

Izvor: Eurobarometar

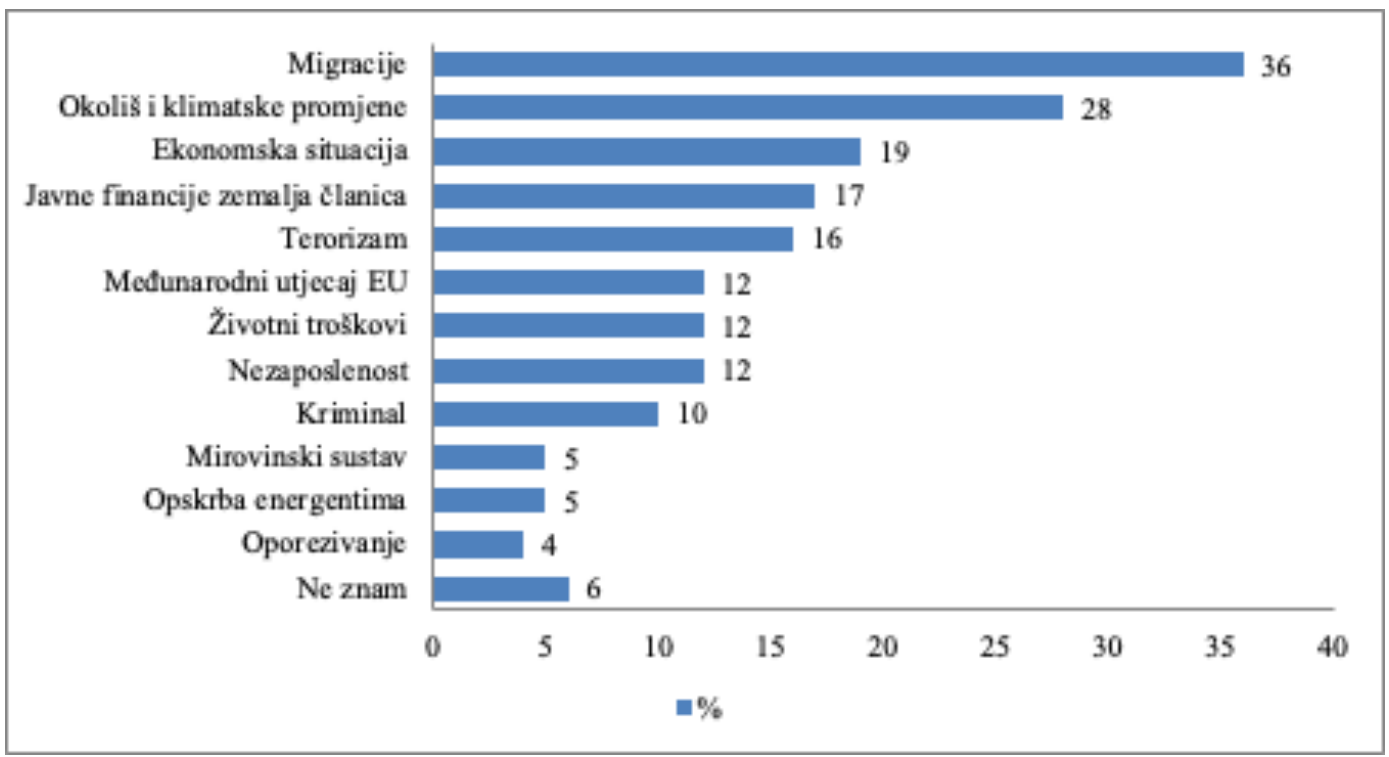

Jedna od temeljnih karakteristika suvremenog diskursa vezanog za migracije u EU-u je kontrast između negativnog predstavljanja tražitelja azila i ilegalnih migranata i argumenata kojima se ističe

7 ec.europa.eu (2019) https:/ec.europa.eu/commfrontoffice/publicopinion/index.cfm/Survey/getSurveyDetail/instruments/ standard/yearFrom/2018/yearTo/2020/surveyKy/2255 (pristupljeno: 11. 2. 2020.) 
nužnost povećavanja radne snage s ciljem ekonomskog rasta (Huysmans, 2000). Stoga, uz ugrozu ekonomskog blagostanja, postojećih struktura moći i kulturnog identiteta, migracije su čest uzrok tenzija na međunarodnoj razini (Bali, 2008, str. 471), što se upravo dogodilo u slučaju država koje su dio tzv. balkanskog pravca migracija. Tijekom migracijske krize preko balkanskog pravca migracija prošlo je oko 764000 migranata $^{8}$. Države koje čine balkanski pravac migracija kategoriziraju se kao tranzitne zemlje, odnosno zemlje preko čijeg teritorija migranti prelaze isključivo s ciljem kako bi se domogli zemalja koje su njihove ciljne destinacije?

Bitno je ukazati na način na koji je Hrvatska regulirala suradnju i odnose s ostalim državama na balkanskom pravcu migracija. Ti odnosi nisu prošli bez problema, posebno kada su u pitanju Republika Srbija, Mađarska i Republika Slovenija, odnosno države s kojima Hrvatska dijeli kopnenu granicu (Jakešević i Tatalović, 2016). Hrvatska kao tranzitna zemlja tada je primijenila humanitarni pristup, a fokus je bio na brzom transferu migranata prema zemljama koje su konačno odredište migranata (Njemačka, Austrija i skandinavske zemlje). Jakešević i Tatalović (str. 1253) navode kako je Hrvatska primijenila humanitarni umjesto sigurnosnog pristupa iz dva razloga. Prvo, zbog unutarnjega političkog stanja, socijaldemokratska Vlada nastojala je popraviti rejting (engl. rating) kod liberalnoga biračkog tijela. Drugo, u kontekstu vanjske politike, vladajuća politička elita humanitarnim pristupom nastojala je pridobiti podršku Njemačke kako bi osnažila vlastiti međunarodni utjecaj. Međutim, problem nekontroliranog priljeva migranata između Hrvatske i susjednih država često nije rješavan na bilateralnoj ili multilateralnoj razini, nego su sekuritizirajući akteri, odnosno političke elite, putem medija pridodavali sigurnosni značaj migrantima $i$, ovisno o pojedinoj državi, sekuritizirali ili desekuritizirali pojam migracija.

Podizanje fizičkih barijera na granicama Slovenije i Mađarske implicira kako je problem sekuritizacije migracija na nacionalnoj razini prisutan i posljedično može dovesti do zatvaranja migracijskih pravaca prema zemljama koje su konačno odredište migranata. Potaknuta iskustvima za vrijeme i nakon migracijske krize iz 2015. godine, Republika Hrvatska učinila je određene napore kako bi u budućnosti ponudila bolje odgovore na sigurnosne izazove koje donosi nekontroliran priljev migranata. Uz ranije navedene izmjene Zakona o nadzoru državne granice i dopune Zakona o obrani, Hrvatska je, većinom glasova u Saboru, 2017. godine, dobila i novu Strategiju nacionalne sigurnosti ${ }^{10}$. Za razliku od prvotne iz 2002. godine, u novoj su Strategiji masovne migracije predstavljene kao važan izvor sigurnosnih ugroza te im je posvećena značajno veća pažnja. Tako se Strategiji iz 2002. godine pojam migracija spominje samo 4 puta i to uglavnom uz terorizam, organizirani kriminal, trgovinu drogom i oružjem, kao „značajne sigurnosne rizike"11. S druge strane, u novoj Strategiji pojam migracija spominje se čak 19 puta i to u kontekstu jednog od glavnih sigurnosnih problema s kojima bi se Hrvatska i EU mogle susresti u budućnosti. Kao generator masovnih migracija u budućnosti, u novoj Strategiji spominju se klimatske promjene, siromaštvo, politička nestabilnost u državama sjeverne Afrike, Bliskog istoka, Kavkaza i srednje Azije, a navodi se kako migracije predstavljaju „socijalni, razvojni, gospodarski, politički, kulturološki, zdravstveni, integracijski i sigurnosni izazov za europska društva“"12. Uz nadopunjavanje postojećih zakonskih akata, bitno je

8 www.frontex.europa.eu (2017) https://frontex.europa.eu/along-eu-borders/migratory-routes/western-balkan-route/ (pristupljeno: 21. 1. 2020.)

9 Države koje predstavljaju konačno odredište migranata su: Njemačka, Austrija i Švedska; dok su zemlje tzv. balkanskog pravca migracija: Grčka, Sjeverna Makedonija, Bugarska, Srbija, Bosna i Hercegovina, Mađarska, Hrvatska i Slovenija.

10 www.index.hr (2017) https:/www.index.hr/vijesti/clanak/hrvatska-dobila-novu-strategiju-nacionalne-sigurnosti/982691.aspx (pristupljeno: 11.01.2020.)

11 www.uvns.hr (2020) https://www.uvns.hr/UserDocsImages/dokumenti/nacionalna-sigurnost/Strategija-nacionalne-sigurnostiRH.pdf (pristupljeno: 10. 2. 2020.)

12 www.uvns.hr (2020) https://www.uvns.hr/UserDocsImages/dokumenti/nacionalna-sigurnost/Strategija\%20nacionalne\%20 sigurnosti\%20RH.pdf (pristupljeno: 10. 2. 2020.) 
spomenuti i modernizaciju u tehnološkom pogledu u sklopu koje je hrvatski MUP dobio moderne helikoptere za nadzor granica ${ }^{13}$, a od 1. srpnja 2016. godine, 19 modernih kamera i 14 radara nadzire hrvatski dio Jadranskog mora od nelegalnih ulazaka krijumčara i mogućih migranata u hrvatske teritorijalne vode ${ }^{14}$.

Prema izvješću Fonda za mir (FFP - Fund for peace) iz 2018. godine, najnestabilnije države (Južni Sudan, Somalija, Sirija, Srednjoafrička Republika, Kongo, Sudan, Čad, Afganistan, Irak) upravo su one iz kojih se u budućnosti mogu očekivati novi migracijski tokovi prema EU-u ${ }^{15}$. Osim zemalja koje su konačno odredište migranata, može se očekivati veliki migracijski pritisak na tranzitne zemlje Balkanskog poluotoka koji se, u geostrateškom pogledu, smatra slabom karikom u pogledu migracijskih kretanja (Zorko, 2018). Hrvatska bi tako mogla postati „slijepa ulica“ i time bi se našla u vrlo nepovoljnom položaju. Upravo je to jedan od glavnih razloga zbog kojih su, nakon razdoblja migracijske krize iz 2015. godine, iregularne migracije postale važna tema političkog diskursa u Hrvatskoj.

\section{Teorijski okvir istraživanja}

Do završetka hladnog rata sigurnost se proučavala uglavnom u kontekstu korištenja vojne moći, no predstavnici Kopenhaške škole (Barry Buzan, Ole Wæver i Jaap de Wilde, 1998) 1990-ih su godina na tradicionalno shvaćanje pojma sigurnosti odgovorili kritikom i ukazali na njezin širi kontekst ističući nevojne prijetnje kao značajan izvor ugroze. Kopenhaška škola nudi širi pogled proučavajući svojstva sigurnosti unutar pet različitih sektora: vojni, politički, ekonomski, ekološki i socijetalni. U radu će se koristiti teorija sekuritizacije kao analitički okvir koji počiva na temeljima konstruktivizma. Onuf (1989) navodi kako konstruktivizam nije teorija, nego pristup koji se može primijeniti na svim poljima društvenih istraživanja. Prema shvaćanju konstruktivista, sve što znamo o svijetu koji nas okružuje produkt je društvenog konstrukta, odnosno znanje je resurs kojeg ljudi rabe u svakodnevnom životu za konstrukciju društvene stvarnosti istraživanja (Onuf, 1998, str. 58, prema Kolodziej, 2005, str. 206).

Sekuritizacija je proces u kojem je određeni problem putem govornog čina od strane sekuritizirajućeg aktera predstavljen kao egzistencijalna prijetnja koja zahtjeva poduzimanje izvanrednih mjera izvan granica regularne političke procedure (Buzan, Wæver, de Wilde, 1998). Definicija sekuritizacije na tragu je Wolfersovog (1952) shvaćanja sigurnosti koji navodi kako sigurnost nikada ne može biti promatrana objektivno, jer se gotovo uvijek radi o subjektivnoj procjeni ili pretpostavci. Emmers (2010, str. 136) navodi kako su sekuritizirajući akteri najčešće državna elita koja kroz govorni čin određeni problem transferira iz sfere politizacije u sferu sekuritizacije. Sekuritizirajući akteri putem govornog čina pridodaju sigurnosni značaj referentnim objektima „na koje se gleda kao da su egzistencijalno ugroženi i koje imaju legitimno pravo za opstankom“ (Buzan i sur., 1998, str. 36). U slučaju migracija kao sigurnosne ugroze, kao referentni objekt najčešće se navode kulturna homogenost, ekonomsko blagostanje i nacionalna sigurnost (Huysmans, 2000).

13 www.jutarnji.hr (2016) https://www.jutarnji.hr/vijesti/hrvatska/hrvatski-mup-ima-novi-helikopter-za-nadzor-granice-evocime-je-sve-opremljen/4479974/ (pristupljeno: 14. 2. 2020.)

14 www.jutarnji.hr (2016) https://www.jutarnji.hr/vijesti/hrvatska/hrvatska-dobiva-najmoderniji-sustav-nadzora-stizu-radari-ikamere-za-schengen-otkrivamo-gdje-ce-sve-biti-postavljeni/4049031/ (pristupljeno: 14. 2. 2020.)

15 www.fundforpeace.org (2018) https://fundforpeace.org/fsi/wp-content/uploads/2018/04/951181805-Fragile-States-IndexAnnual-Report-2018.pdf (pristupljeno: 8. 2. 2020.) 
Migracije se uglavnom proučavaju unutar socijetalnog sektora kao nevojna prijetnja koja olakšava izvođenje terorističkih napada ${ }^{16}$, predstavljaju prijetnju ekonomiji ${ }^{17}$, a najčešće se spominje sigurnosna ugroza koju migranti predstavljaju naspram kulturnog identiteta i socijalne kohezije unutar država koje su njihova konačna odredišta (Bali, 2008, str. 471). Iako dolazak velikih skupina stranaca može uzrokovati napetosti kod domicilnog stanovništva, definiranje problema i upravljanje takvim situacijama, pa i provođenje sekuritizacije kroz govorni čin, ovisi o političkim i društvenim procesima (Elias i Scotson, 1994, prema Huysmans, 2006, str. 2). Stoga, sekuritizacija migracija proizlazi iz samog jezika, odnosno različitih sekuritizirajućih aktera koji putem govornog čina označavaju referentni objekt ugroženim (Bigo, 2002, str. 65).

\section{Izborna kampanja kao dio političkog spektakla}

Izborna kampanja je kulminacija političke komunikacije, a Lalić i Kunac (2010) je definiraju kao organiziranu komunikacijsko-propagandnu aktivnost političkih stranaka i kandidata koji imaju za cilj osiguravanje izborne potpore u svrhu ostanka na vlasti, osvajanja vlasti ili utjecanja na vlast. Šiber (2003, str. 210) navodi kako je politička kampanja kompetitivna djelatnost koja „nužno kombinira prezentiranje određene političke ponude u usporedbi s političkom ponudom konkurencije“. Politička komunikacija, pa i proces sekuritizacije, mogu se promatrati kao spektakl kojeg Edelman (2003) definira kao neprekidno konstruiranje i rekonstruiranje društvenih problema, kriza, neprijatelja i vođa, prijetnji i nada. Politički spektakl je jedan od mehanizama kojim političke elite konstruiraju krize kako bi osnažili ili preoblikovali identitete vlastite publike kroz Scmittovsku podjelu između ugroženih „nas“, i „njih“ koji nas ugrožavaju (Edelman, 1988, prema Szalai, 2017, str. 3). Migracije su u kontekstu sigurnosti postale jedna od važnijih tema političkog spektakla (Huysmans, 2000), što je potvrđeno i na predsjedničkim izborima u Hrvatskoj 2019./2020. godine.

Danas je političku komunikaciju nemoguće zamisliti bez posredovanja medija koji imaju ključnu ulogu u prenošenju političke komunikacije. Mediji imaju ključnu ulogu u posredovanju informacija između političkih aktera i javnosti (Grbeša, 2008), a njihova uloga do izražaja dolazi posebno za vrijeme izbora kada se građani informiraju o političkim opcijama ili kandidatima kako bi utvrdili koji najbolje odgovara njihovim očekivanjima (Peruško, Vozab, 2018, str. 454). Medijski sadržaj „rekonstruira društvene svjetove, povijesti i eshatologije, evocirajući razloge za zabrinutost, nadu i pretpostavke o tome što treba biti zapaženo, na što se ne treba obazirati, koji su ljudi vrijedni poštovanja i junaci, a koji su vrijedni prijezira" (Edelman, 2003, str. 39).

Meyer (2003, str. 25) navodi kako za medijski sadržaj vrijedi određeni skup pravila prikazivanja koji je istovjetan s pravilima inscenacije u kazalištu. Inscenacija u teatrološkom smislu, predstavlja opis tehnika koje se primjenjuju u prikazivanju određenog događaja publici (Fischer-Lichte, Pflug, 2000, prema Meyer, 2003, str. 25). Stoga predsjedničku kampanju možemo promatrati kao oblik medijske inscenacije kroz dva modela: a) Mitski sukob junaka koji inscenira konkurenciju u političkoj areni kao sudbonosan dvoboj junaka, u ovom slučaju, predsjedničkih kandidata, čiji je politički sukob predstavljen kao odlučna bitka između nadosobnih sudbonosnih sila (Meyer, 2003), b) Verbalni okršaj koji uz maksimiziranje emocija i uzbuđenja stvara sukob i krajnju napetost. Moderator (voditelj) navodi suparnike na taj učinak enormnim sučeljavanjem njihovih iskaza i protuiskaza (str. 27).

16 Bove i Böhmelt (2017) u svom su istraživanju na 145 država potvrdili hipotezu kako su migracije važan mehanizam difuzije terorizma u države koje su konačno odredište migranata. One mogu poslužiti kao poveznica između terorističkih grupa koje tako razmjenjuju ideje, taktike i vještine, pogotovo jer su radikalizirane osobe u zemljama Zapada često neiskusne i nemaju resurse za izvedbu terorističkih napada (str. 27).

17 Bali $(2008$, str. 471, 478) navodi kako migranti mogu uzrokovati dodatno opterećenje za državni proračun u pogledu socijalnog stanovanja, novčanih naknada, obrazovanja i zdravstvene zaštite. Također, kao jeftinija radna snaga povećavaju konkurenciju domicilnom stanovništvu na tržištu rada. 
Unatoč predviđanjima o smanjenju utjecaja nakon pojave interneta, televizija je i dalje dominantan medij te je donijela ključne promjene koje su intenzivirale medijatizaciju politike i iz temelja promijenile prirodu političke komunikacije (Grbeša, 2008, str. 31). Kampanja za predsjedničke izbore u Hrvatskoj 2019./2020. godine nije bila iznimka. Televizija je bila glavni medij putem kojeg su kandidati predstavljali svoj program. Iako su se kandidati oglašavali putem oglasa na internetu, radijskih i TV spotova, billboard plakata, najveću pažnju glasača privukla su četiri televizijska sučeljavanja, i to dva sučeljavanja na HRT-u i po jedno sučeljavanje na Nova TV i RTL-u ${ }^{18}$. Prema Jarmanu (2018, str. 166) predsjednička sučeljavanja publici pružaju kvalitetan način informiranja o kandidatima i izbornim temama. Tako glasači procjenjuju snagu argumenata kako bi bolje shvatili problematiku sučeljavanja i na koncu donijeli glasačku odluku. Skoko (2005) navodi kako se radi o prvorazrednom televizijskom spektaklu na kojem do izražaja dolaze vještine i znanje kandidata, ali i pogreške zbog kojih mogu ugroziti vlastite izborne rezultate. McNair (2003, prema Skoko, 2005, str. 71) smatra kako televizijsko sučeljavanje u najčišćem obliku prezentira liberalno-demokratsku ulogu elektroničkih medija. Takav format emisije zauzima ulogu posrednika između javnosti i političara, pri čemu se javnosti pruža pristup političkom diskursu u njegovom sirovom obliku.

\section{Kritička analiza diskursa}

U ovom se radu koristi Faircloughova kritička analiza diskursa kojom se, između ostalog, istražuje i korištenje jezika kao alata za uspostavljanje moći u sklopu državnih institucija ili društva općenito (Fairclough, 1992; 1993; 1995; 2003; 2005). Kritička analiza diskursa ima za cilj ispitati povezanost diskurzivnih i društvenih praksi, odnosno determinirati ulogu koju diskurs ima u društvu. Njome se razotkriva učinak odnosa moći i ideologije na diskurs, kao i konstruktivni učinak koji diskurs ima na društvene identitete, društvene odnose i sustave znanja i vjerovanja, čega sudionici diskursa ne moraju uvijek biti svjesni (Fairclough, 1992, str. 12). Diskurs predstavlja oblik društvene i historijske prakse koja se odnosi na izgovorene i napisane jezične oblike društveno oblikovane semiotičke komunikacije (Fairclough, 1993, str. 134, prema Watson, 2009). Foucault (1972, str. 49, prema Mills, 1997, str. 17) navodi kako diskurs ne treba promatrati kao niz različitih znakova ili rečenica, nego kao prakse koje sustavno tvore objekte o kojima govore. Dakle, diskurs je nešto što proizvodi nešto drugo, a ne nešto što postoji samo po sebi i što može biti analizirano kao izoliran slučaj (Mills, 1997, str. 17).

Prema Faircloughu, kritička analiza diskursa sastoji se od: a) analize teksta, b) analize diskurzivne prakse i c) analize društvene prakse, odnosno, općenito govoreći, predstavlja analizu odnosa između tri navedene razine (Fairclough, 1995, str. 57, prema Car i Vrtič, 2016, str. 149). Analiza teksta odnosi se na leksiku, gramatiku, koheziju i strukturu teksta; analiza diskurzivne prakse odnosi se na procese proizvodnje, distribucije i konzumacije teksta; analiza društvene prakse odnosi se na društveni (u ovom slučaju politički) kontekst vezan za određeni komunikativni događaj te pitanja ideologije i moći (Car i Vrtič, 2016, str. 149).

Pod pojmom tekst, Fairclough podrazumijeva i govorni i pisani jezik, vizualne elemente te zvuk. Tekst kao element društvenih zbivanja donosi određene promjene koje utječu na naše znanje, uvjerenja, stavove i vrijednosti. Također, može uzrokovati dugoročne efekte, kao što primjerice

18 Primjerice, sučeljavanje na HRT-u koje se održalo 17. prosinca 2019. godine, pratilo je 699.686 gledatelja (https://www.tportal. $\mathrm{hr} /$ vijesti/clanak/suceljavanje-predsjednickih-kandidata-na-hrt-u-gledalo-gotovo-700-000-ljudi-20191218 (pristupljeno: 19. 2. 2020.), sučeljavanje na RTL-u 30. prosinca 2019. pratilo je 874.886 gledatelja (https://net.hr/danas/hrvatska/rtl-je-debatomoborio-rekord-prvo-suceljavanje-kolinde-i-milanovica-gledalo-je-vise-od-milijun-gledatelja/ (pristupljeno: 22. 2. 2020.), drugo sučeljavanje na HRT-u 2. siječnja 2020. godine pratilo je gotovo milijun gledatelja (https://www.vecernji.hr/vijesti/predsjednickiduel-na-htv-u-gledalo-139-gledatelja-1370181 (pristupljeno: 22.2.2020), a sučeljavanje na Nova TV 3. siječnja 2019. godine pratilo je oko 950.000 gledatelja (https://novatv.dnevnik.hr/clanak/zanimljivosti/gledatelji-ponovno-odabrali-novu-tv---589382. html (pristupljeno: 22. 2. 2020.). 
stalno oglašavanje proizvoda doprinosi u oblikovanju identiteta osoba kao potrošača (Fairclough, 2003, str. 8). Ovdje možemo povući paralelu potrošača s glasačima i političkim akterima koji svoj proizvod nastoje uskladiti s potrebama javnosti i plasirati ga na tržište. Kako bi politički proizvod na odgovarajući način predstavili biračima i izdigli ga iznad konkurentskog političkog proizvoda, stranke i kandidati političkom proizvodu nastoje dati „atraktivnu ambalažu“ (Street, 2003, str. 157), odnosno diskursom konstruiraju društvenu zbilju s ciljem proizvodnje željenog učinka, čiji je krajnji cilj pobjeda na izborima, preuzimanje ili ostanak na vlasti.

Van Dijk (2018, str. 243) smatra kako su migracije kompleksan sociopolitički fenomen i jedan od fundamentalnih načina za njihovo istraživanje je analiza svojstava različitih oblika teksta ili jezika o migrantima. Stoga je kritička analiza diskursa, kao metoda, prikladna za istraživanje procesa sekuritizacije koja per se predstavlja govorni čin. Jezik služi kao alat za postizanje ciljeva i generiranja moći u društvu, a ključan element u govornom činu je autoritet, odnosno izvor informacije koji kod javnosti ima legitimitet (Fairclough, 2005). Autoritet u ovom slučaju predstavljaju predsjednički kandidati koji govornim činom konstruiraju društvenu zbilju, odnosno svojim stavovima o problemu masovnih migracija, pokušavaju utjecati na mišljenje potencijalnih glasača.

\section{Empirijska analiza}

Na televizijskim sučeljavanjima Zoran Milanović i Kolinda Grabar-Kitarović uglavnom su koristili elemente negativne kampanje ${ }^{19}$. Zoran Milanović kritizirao je politiku Kolinde Grabar-Kitarović navodeći njezinu neodlučnost kao veliki propust za vrijeme migracijske krize iz 2015./2016. godine. Također, često je u negativnom kontekstu isticao zagovaranje političkih krugova bliskih Kolindi Grabar-Kitarović za postavljanje fizičkih barijera na granice te ju je u izjavama vezanim za migracije optuživao zbog bilateralnih susreta s Viktorom Orbánom, koji je zbog sekuritizacije migracija naišao na oštre kritike od strane međunarodne zajednice. S druge strane, Kolinda Grabar-Kitarović je migracijsku krizu iz 2015. označavala kao „kaos“ za koji je isključivo bio odgovoran Zoran Milanović kao tadašnji premijer. Također, za postavljanje „žilet-žice“ na granice Republike Slovenije i Mađarske, optužila je izravno Zorana Milanovića i njegov način vođenja vanjske politike. Stoga, izbornu kampanju, kao i sučeljavanje, možemo promatrati kako svojevrsni nastavak debate između navedenih političkih aktera koji su, nakon 2015., i na predsjedničkim izborima 2019./2020., na sličan način nastavili izražavati različitosti u stavovima oko masovnih migracija kao sigurnosne ugroze.

Kako je ranije naznačeno, kao jedinica analize u ovom istraživanju koriste se izjave predsjedničkih kandidata Zorana Milanovića i Kolinde Grabar-Kitarović koje su prezentirane u tri televizijska sučeljavanja. Sučeljavanja su organizirale tri hrvatske televizijske mreže s nacionalnom koncesijom (Hrvatska radiotelevizija, RTL Televizija i Nova TV). ${ }^{20}$ Analiziraju se sve izjave predsjedničkih kandidata vezane za problem nekontroliranog priljeva migranata, odnosno kritičkom analizom diskursa analizira se jezik kojim su se predsjednički kandidati služili u izjavama vezanim za problem masovnih migracija. Empirijska analiza podijeljena je kronološki, od prvog prema posljednjem televizijskom sučeljavanju. Radi važnosti konteksta u kojem su prezentirane, izjave su analizirane naizmjenično.

19 Negativna izborna kampanja je bilo kakva komunikacija za vrijeme političke kampanje kojom se naglašavaju negativne osobine suparnika ili suparničke politike. Mnogi se autori slažu kako je negativna kampanja dio demokratskog procesa i kako je poželjna jer obogaćuje politički diskurs, stimulira interes birača i daje biračima bolji uvid u kvalitete i slabosti političkih aktera (Vaccari, Morini, 2014, str. 20).

20 Nova TV je također organizirala sučeljavanje predsjedničkih kandidata, no ono nije predmet ovog istraživanja s obzirom kako se u njemu nije raspravljalo o temi problema masovnih migracija. 


\subsection{Prvo sučeljavanje u organizaciji Hrvatske radiotelevizije (održano 17. prosinca 2019. godine) - kritička analiza diskursa}

$\mathrm{Na}$ sučeljavanju prije prvog kruga predsjedničkih izbora sudjelovalo je svih 11 predsjedničkih kandidata, no kod pitanja o problemu migracija Milanović i Grabar-Kitarović svoje su stavove iznosili debatirajući međusobno, uz potpuno ignoriranje ostalih predsjedničkih kandidata. Drugim riječima, branili su vlastite, a kritizirali tuđe poteze iz 2015./2016. godine. Na pitanje voditelja Treba li zbog migrantske krize na granicu postaviti vojsku? Kolinda Grabar-Kitarović odgovorila je sljedeće:

„Nakon onog totalnog kaosa kojeg smo imali 2015./2016. godine, kad su se samo propuštali migranti, za koje sad vidimo da ih se više od polovice vraća jer nisu zapravo pravi azilanti. Predložila sam upravo to, da vojska pomaže policiji. I tada smo 2016. godine omogućili promjene zakona koji sad već predviđaju da vojska dođe u pomoć policiji u nadzoru hrvatske granice. No, o tome u konačnici odlučuje policija i njihove su procjene u ovom trenutku da to nije potrebno. Oni uspješno štite granicu, ne samo Hrvatske, nego i najdužu granicu EU, zašto je konačno gospođa Merkel počela izražavati zahvalnost. Ono o čemu treba voditi računa je da se kupi dodatna oprema za vojsku i policiju za nadzor granice. I naravno, nemojmo zaboraviti ljude u Hrvatskoj koji žive u područjima kroz koje prolaze ilegalni migranti." (Grabar-Kitarović, 2019)

Grabar-Kitarović migracijsku krizu u Hrvatskoj označava kao totalni kaos, kojeg možemo definirati kao opasno stanje izvan kontrole. Time implicitno ukazuje na Zorana Milanovića kao osobu koja je bila na čelu tadašnje Vlade i koja je odgovorna za takvo stanje, odnosno propuštanje migranata. Nakon toga, navodi kako više od polovice propuštenih osoba nisu pravi azilanti. Dijeleći prave azilante, od ilegalnih, odnosno ekonomskih migranata donositelji odluka u državama, često pokušavaju pooštriti migracijske politike i označiti migrante kao sigurnosnu prijetnju (Huysmans, 2006, str. 58). Kao rezultat toga, K. Grabar-Kitarović komunicira s pozicije moći i, kao predsjednica i vrhovna zapovjednica Oružanih snaga, ističe kako je upravo ona zaslužna za promjene Zakona o obrani kojima je vojsci omogućeno pružanje potpore policiji u zaštiti državne granice. Zahvaljujući izmjenama zakona, K. Grabar-Kitarović smatra kako je postojeće stanje zadovoljavajuće i hvali policiju za uspješnu zaštitu hrvatske granice i najduže granice EU-a, implicirajući na najdužu „vanjsku granicu“ EU-a ${ }^{21}$. Grabar-Kitarović koristi sličan diskurs kojeg je koristila slovenska politička elita koja je sekuritizirala migracije i uvela izvanredne mjere postavljanjem fizičkih barijera na granici s Hrvatskom. Referentni objekti koje su sekuritizacijski akteri u Sloveniji predstavili ugroženima su: sama država, Europska unija i Schengenska zona (Vezovnik, 2017, str. 49).

K. Grabar-Kitarović time također implicira kako kvalitetan angažman hrvatske policije izravno utječe i na sigurnost cijele Europske unije, stavljajući Hrvatsku kao prvu granicu obrane u slučaju ponavljanja migracijske krize. Kao potvrdu navedene tvrdnje, poziva se na odobravanje Angele Merkel koja u ovom slučaju predstavlja autoritet ${ }^{22}$, a koju je K. Grabar-Kitarović 2015. označavala kao odgovornu osobu za migracijsku krizu ${ }^{23}$. Na kraju izjave, K. Grabar-Kitarović ističe kako se ne smije zaboraviti na građane Hrvatske koji žive u pograničnim područjima. Time implicira kako su oni posebno ugroženi zbog ilegalnih migranata. Korištenjem pridjeva ilegalni, pobuđuju se predodžbe o migrantima koji su skloni kriminalitetu i kao takvi predstavljaju sigurnosnu ugrozu.

21 Ova tvrdnja nije točna, jer članice EU-a koje imaju dužu „,vanjsku kopnenu granicu“ od Hrvatske su Finska, Švedska i Rumunjska. Teško je utvrditi razlog iznošenja netočne tvrdnje. Moguće je da se radi o namjernoj manipulaciji činjenicama, ili je riječ o nepoznavanju geopolitičkih prilika na razini EU-a.

22 Pojam autoriteta definira se kao svojstvo osobe, uloge, službe ili države da čini legitimnim, prividno ili stvarno, radnje i naredbe učinjene u svoje ime (Pravni leksikon, 2007, str. 57 prema Harašić, 2015, str. 408). 
Na jednako pitanje o dovođenju vojske na granicu Republike Hrvatske, Zoran Milanović je odgovorio:

„Nazivati operaciju hrvatske države iz jeseni 2015. kaosom, može samo um koji je navikao na represiju i koji na život, politiku i ljudska bića gleda kroz optiku represije. Naravno da bih u svakom trenutku 2015., a imam jedini to iskustvo, veliko iskustvo, reagirao da je bilo što ugroženo u Hrvatskoj. 500 tisuća ljudi je prošlo da ni jedna taraba u Hrvatskoj nije nakrivljena, a kamoli srušena. Ni jedan euro nije nestao. Sve je to zato jer smo htjeli biti ljudi, ali isto tako i lukavi u zaštiti nacionalnih interesa. Uvijek je postojao plan B. Dok su drugi išli Orbánu u Budimpeštu i Vučiću u Beograd, ja sam razgovarao s Angelom Merkel koja je naravno htjela da se u Hrvatskoj zadrži 100 tisuća ljudi. Mi nismo, nego smo ih elegantno i civilizirano transportirali, ružna riječ, na sjever. To je bilo tada, danas policiji treba pomoći.“ (Milanović, 2019)

Milanović u potpunosti ignorira ostale protukandidate i izravno se obraća Kolindi GrabarKitarović. Kao tadašnji premijer, angažman oko rješavanja nekontroliranog priljeva migranata naziva operacijom. Radi se o izrazu koji je uglavnom svojstven vojnoj terminologiji, čime Milanović želi ukazati na ozbiljnost i profesionalni pristup u rješavanju migracijske krize. Također, izražava suosjećajnost imenujući migrante ljudskim bićima, nakon čega komunicira s pozicije moći pozivajući se na veliko iskustvo, kojeg jedino on posjeduje i temeljem kojeg je procijenio kako 2015./2016. godine nije bilo razloga za sekuritizaciju migracija. Milanović migrante svodi na brojeve (500 tisuća) kako bi povećao efekt ozbiljnosti i opsežnosti provedene operacije. Također, desekuritizira migrante navodeći kako nisu nakosili niti jednu tarabu u Hrvatskoj, a kamoli ozbiljno ugrozili hrvatske građane ili ugrozili ekonomsku stabilnost države. Naime, Huysmans (2000) navodi kako su migracije unutar političkog diskursa često interpretirane kao prijetnja kulturalnoj homogenosti, a imigranti, tražitelji azila, izbjeglice i ostali stranci, kod domaćeg stanovništva stvaraju strah od ugroze ekonomskog blagostanja i preopterećenja tržišta, što Milanović, u ovom slučaju, opovrgava.

Z. Milanović u nastavku zaoštrava retoriku temeljem argumenata kako je, unatoč svemu, lukav političar koji je imao plan $B$, čime implicira kako je kao premijer, u određenim okolnostima, bio spreman uvesti izvanredne mjere i sekuritizirati migracije. Kao i K. Grabar-Kitarović, Z. Milanović nastavlja s polarizacijom i služi se dihotomijom „ja“ $v s$. „drugi“. Korištenjem zamjenica ja ili mi želi se stvoriti osjećaj pripadnosti, dok se korištenjem zamjenice oni želi napraviti distinkcija između grupa ljudi (Mehan, 1997, str. 258-259). U ovom slučaju, Milanović se ne distancira od migranata, nego od Kolinde Grabar-Kitarović, koju kritizira zbog odlaska Orbánu u Budimpeštu i Vučiću u Beograd. Milanović izjednačava K. Grabar-Kitarović s „negativcima“ Viktorom Orbánom i Aleksandrom Vučićem, političarima s kojima se tijekom premijerskog mandata često sukobljavao i čiju je politiku u predsjedničkim izborima 2019./2020. oštro kritizirao.

Nadalje, koristi se osobnom zamjenicom ja i to u pozitivnom kontekstu razgovora s Angelom Merkel, koju je, unatoč njezinu autoritetu, „spriječio“ da u Hrvatskoj zadrži 100 tisuća ljudi. Nakon toga, služi se zamjenicom mi kada ističe kako su migranti elegantno i civilizirano transportirani na sjever. Podboj (2011, str. 131) navodi kako se radi o mehanizmu koji je tipičan primjer jezične manipulacije u političkom diskursu. Naime, prilikom uporabe zamjenice ja, Milanović je istaknuo kako je Hrvatsku „spasio“ od 100 tisuća migranata, dok se u slučaju transportiranja migranata koristi zamjenicom mi i tako otklanja fokus od sebe i distancira se od negativnog aspekta navedenog poteza (Podboj, 2011). Budući da postoje ozbiljne implikacije ponavljanja masovnih migracija prema EU, što je ranije istaknuto, Milanović ne želi predstaviti sebe kao predsjednika koji je, unatoč svemu, spreman ponovno primijeniti humanitarni pristup u rješavanju problema nekontroliranog priljeva migranata. 
Korištenjem vremenskog priloga tada, sugerira na migracijsku krizu 2015./2016. „kada je bilo sve pod kontrolom“, dok u kontekstu vremenskog priloga danas, navodi kako je policiji potrebna pomoć u zaštiti granice, odnosno mogućnost sekuritizacije migracija ostavlja otvorenom.

Kolinda Grabar-Kitarović iskoristila je mogućnost replike i ponovno se obratila Zoranu Milanoviću navodeći:

„Naravno da moramo biti suosjećajni onim pravim azilantima, a to treba raditi tako da se otklanjaju uzroci njihovih migracija na samom početku. Međutim, postoje razlike između azilanata i ilegalnih migranata. Legalni prijelazi Republike Hrvatske otvoreni su za svakoga tko hoće zatražiti azil. Međutim puno njih hoće prijeći ilegalno. Naša policija tu radi sjajan posao. Ja ne dopuštam da se njih vrijeđa." (Grabar-Kitarović, 2019)

K. Grabar-Kitarović uglavnom polarizira pojmove „ilegalni migranti“ vs. „pravi azilanti“, „ilegalno“ vs. „legalno“, „ja“ vs. „oni“, „nas“ vs. „njih“. Naglašava razliku između ilegalnih migranata od pravih azilanata, prema kojima izražava suosjećanje. S druge strane, terminom ilegalni migranti označava tuđince koji nisu dobrodošli u već formiranu društvenu zajednicu. Huysmans (2006, str. 51) navodi kako se na takav način stvaraju interpretacijski okviri, u ovom slučaju migranata, s ciljem proizvodnje povjerenja u političke aktere i straha od migranata, odnosno proizvodnjom razlikovanja „onih kojima se može vjerovati“ od „onih kojih bismo se trebali bojati“. Strah je bitan element za legitimaciju nacionalnih i međunarodnih akcija u pogledu ograničavanja migracija (Zorko, 2018), a posrednici mogu biti i političke elite koje strah šire putem masovnih medija i popularne kulture (Furedi 2007, prema Zorko 2018). Korištenjem termina ilegalni ili ilegalno politički akteri često kreiraju sigurnosni diskurs kako bi potvrdili uvođenje izvanrednih mjera u sklopu sekuritizacijskog procesa (Lindqvist, 2017, str. 29). Tako se migranti predstavljaju kao sigurnosna prijetnja i problem, što često dovodi do kriminalizacije i pokretanja različitih aktivnosti s ciljem ograničavanja prekograničnog kretanja određenih kategorija osoba (Iosifides, 2018, str. 98). Ipak, Grabar-Kitarović koristi i umjerenu retoriku, navodeći kako su legalni prijelazi Republike Hrvatske otvoreni za prave azilante, dok ilegalne migrante kriminalizira i odobrava sjajan posao policije koja ograničava prolaz onima koji nisu poželjni u Republici Hrvatskoj. Bitno je napomenuti kako Grabar-Kitarović tri puta koristi osobnu zamjenicu njih (njihovih), koja se odnosi na migrante. Time do izražaja ponovno dolazi polarizacija između nas i njih, što je prema Podboj (2011, str. 131), također jedan od mehanizama jezika manipulacije. Na kraju izjave, K. Grabar-Kitarović ponovno ublažava retoriku u rečenici „ja ne dopuštam da se njih vrijeđa“. Ovdje nije jasno na koga se odnosi zamjenica njih, no može se pretpostaviti kako K. GrabarKitarović ne misli na policiju, nego na ilegalne migrante, čime ipak ublažava stavove oko migranata kao sigurnosne prijetnje.

Nakon replike K. Grabar-Kitarović, Z. Milanović je iskoristio pravo replike na repliku:

„Ja ne znam je li itko razmišljao o tome, što bi vojska radila na granici? Koje vojne postrojbe bi bile na granici? Jer podsjetit ću, vojska je tu da štiti hrvatski teritorij, građane i imovinu. Vojska je ubojna sila, osim ako nije zadužena za katastrofe gdje pomaže ljudima. Želim da se to osvijesti, što bi vojska radila na granici?“ (Milanović, 2019) 
Milanovićeva replika uglavnom se sastoji od niza retoričkih pitanja i iskaza kojima opovrgava teze K. Grabar-Kitarović o slanju vojske na granicu Republike Hrvatske. Za razliku od pitanja u kojima se traži informacija, kod retoričkih pitanja pošiljatelj ima za cilj pružiti informaciju ili postići određeni učinak (Athanasiadou, 1991). Iako se ne očekuje odgovor na postavljeno retoričko pitanje, ono ima svoga recipijenta, odnosno nekomu je namijenjeno. U ovom slučaju, Z. Milanović se obraća K. GrabarKitarović nizom retoričkih pitanja na koje sam odgovara. Retorička pitanja često se postavljaju kad se želi uspostaviti dominacija nad drugima, a pošiljatelj također može izraziti zabrinutost oko određene situacije (Athanasiadou, 1991). Razvidno je kako Milanović, uz uspostavljanje dominacije, retoričkim pitanjima ima za cilj izraziti zabrinutost oko ideje slanja vojske na granicu dajući do znanja kako se radi, prema njemu, o opasnoj ideji, jer je vojska, kako navodi, ubojna sila.

\subsection{Sučeljavanje u organizaciji RTL televizije (održano 30. prosinca 2019. godine) - kritička analiza diskursa}

Ovo je prvo sučeljavanje u drugom krugu predsjedničkih izbora. Voditelji sučeljavanja nisu postavljali izravna pitanja vezana za sigurnosne rizike masovnih migracija, no predsjednički kandidati odgovarali su na pitanje vezano za vanjsku politiku i odnose s Bosnom i Hercegovinom. U okviru navedenog pitanja, debatirali su i o turskom predsjedniku Recepu Erdoğanu, odnosno o Turskoj u kojoj su migranti zaustavljeni. U tom kontekstu, Z. Milanović je kritizirao K. Grabar-Kitarović zbog bilateralnih sastanaka s Erdoğanom, koja je reagirala na sljedeći način:
„Kako biste vi gospodine Milanović razgovarali s Erdoğanom koji trenutno drži
kontrolu nad milijunima migranata i izbjeglica koji su u Turskoj, da ne krenu put
Hrvatske i put Europske unije? Pogotovo nakon žilet-žice koju ste nam ostavili
u naslijeđe na granicama sa Slovenijom i Mađarskom." (Grabar-Kitarović, 2019)

K. Grabar-Kitarović na samom početku izjave komunicira s pozicije moći postavljajući retoričko pitanje kojim uspostavlja dominantan stav. Kao aktualna predsjednica ističe kako su razgovori s Erdoğanom bili neophodni, jer potonji, prema Grabar-Kitarović, trenutno drži kontrolu nad milijunima migranata $i$ izbjeglica. U ovom sučeljavanju K. Grabar-Kitarović polarizira pojmove „migrant“ vs. „izbjeglica“, gdje pod pojmom migrant smatra sve one koji nisu izbjeglice, uključujući ilegalne migrante i ekonomske migrante, za koje je već ranije izrazila stav kako nisu poželjni u Republici Hrvatskoj. Također, naglašava kako se radi o milijunima migranata $i$ izbjeglica. Interpretacijski okvir u kojemu se koriste brojevi uglavnom se koristi kako bi se migranti označili kao ogromne grupe ljudi koje je nemoguće kontrolirati i koji mogu donijeti probleme društvima u koja dolaze (CunninghamParmeter, 2011). K. Grabar-Kitarović Hrvatsku i EU označava kao ugrožena društva, odnosno referentne objekte koje treba zaštititi od milijuna migranata. Na kraju izjave, navodi kako je „žiletžica“ na granici sa Slovenijom i Mađarskom ostavština loše politike Zorana Milanovića koju je kao premijer vodio za vrijeme migracijske krize 2015./2016. godine. Ovdje je važno istaknuti korištenje posvojne zamjenice nama. Iako nije precizirano na koga se zamjenica odnosi, može se zaključiti kako se radi o građanima Republike Hrvatske. Korištenjem navedene zamjenice pošiljatelj poruke ima za cilj stvoriti vezu između sebe i publike, odnosno izazivati osjećaj pripadnosti samoj grupi i stvoriti iluziju jednakosti s publikom kojoj se obraća (Karlsson, 2018, str. 14). Stvaranje osjećanja pripadnosti vrlo je važno kod političkih aktera kako bi istaknuli zajedničke ciljeve i interese koje dijele s ostatkom društva (Karlsson, 2018). 
Zoran Milanović je na navode Kolinde Grabar-Kitarović reagirao sljedećom replikom:

"Osvrnut ću se na ovaj nevjerojatan komentar gospođe Grabar-Kitarović o žiletžici njezinog prijatelja, malog diktatora Viktora Orbána koji je vratio vlakić u kojem smo mi perfektno, bez ijedne greške, ljude prevozili. Dakle, nikakav Erdoğan ne drži Europu u šaci. Ti jadni ljudi, to nisu krumpiri, to nije kupus. Ti jadni ljudi, njih 658 tisuća, od toga pola žena i djece, su prošli kroz Hrvatsku tako organizirano uz sve vaše opstrukcije. To je bilo 2015. godine, danas Erdoğan više ne može to napraviti, ne drži taj ključ. Ti jadni ljudi, ako se odluče krenuti za Europu, fizički ne mogu doći dalje do Bugarske. Što se tiče žilet-žice, tog trena sam je mogao postaviti, međutim računao sam da će nas djeca pamtiti po čovječnosti, a uvijek sam imao, da se tako slikovito izrazim, metak u cijevi. Ne za migrante, nego metaforički. I rješenje B, žilet-žica, nikakav problem, ali to je HDZ-ov um." (Milanović, 2019)

Z. Milanović ponovno povezuje K. Grabar-Kitarović s „negativcem“ Viktorom Orbánom kojeg pejorativno naziva malim diktatorom ${ }^{24}$. Nakon toga, Milanović značaj incidenta između Hrvatske i Mađarske iz 2015. godine osporava korištenjem umanjenice $v l a k i{ }^{25}$. Također, ponovno u pozitivnom kontekstu koristi zamjenicu $m i$, ističući kako su za vrijeme njegovog premijerskog mandata migranti prevoženi perfektno i bez ijedne greške. Kao i u prvoj TV debati, Milanović je i ovdje izbjegavao koristiti termine migranti, izbjeglice, prognanici, azilanti, umjesto kojih se koristi imenicom ljudi (u ovoj izjavi jadni ljudi). Time želi izraziti suosjećajnost prema migrantima, odnosno pokazuje kako za njega migranti ne predstavljaju sigurnosnu ugrozu jer, kako navodi, polovicu migrantske populacije čine žene i djeca.

Z. Milanović umanjuje važnost sastanka K. Grabar-Kitarović i Erdoğana, kojeg diskreditira navodeći kako više ne drži Europu u šaci. U nastavku izjave, kao bivši premijer optužuje, K. Grabar-Kitarović za opstrukciju humanitarnog pristupa u rješavanju migrantske krize. Ovdje je također bitan kontekst jer Milanović sugerira na izvođenje „operetnog državnog udara“26 za kojeg je optužio GrabarKitarović u kontekstu povjeravanja mandata Tihomiru Oreškoviću koji je, nakon Milanovića, postao predsjednik Vlade RH. Na kraju replike, Milanović i ovdje napominje kako je imao plan B i metak u cijevi, u vidu postavljanja žilet-žice, no od takve ideje se ponovno distancira napominjući kako je to modus operandi HDZ-a čija je kandidatkinja K. Grabar-Kitarović.

24 Ovdje je bitno razmotriti kontekst ove Milanovićeve izjave. Vladajuća politička stranka u Mađarskoj, FIDESZ na čelu s Viktorom Orbánom, iskoristila je izbornu pobjedu 2010. godine i snažnom nacionalističkom retorikom za cilj je imala monopolizaciju političkog prostora. Ukidanje prava različitim manjinama, popunjavanje neovisnih institucija podobnim kadrom i izmjena izbornog sustava, samo su neki od indikatora restriktivne politike FIDESZ-a u Mađarskoj (Szalai, Gőbl, 2015). Navedene promjene, uz gotovo potpunu kontrolu medija i korupciju širokih razmjera, definiraju mađarsku neliberalnu demokraciju na čelu s Viktorom Orbánom (str. 13), što je naišlo na kritiku međunarodne zajednice, posebno institucija EU.

25 U rujnu 2015. godine Hrvatska je prema mađarskoj granici usmjerila vlak pun migranata i naoružanih pripadnika hrvatske policije zbog čega je došlo do izrazito zategnutih odnosa između te dvije zemlje. Političke elite dodatno su intenzivirale ovaj događaj i putem medija slali poruke kako se radi o „velikom međunarodnom incidentu“ u kojem su mađarske vlasti zaustavile vlak s 1000 migranata i 40 naoružanih hrvatskih policajaca. Hrvatski policijski službenici pušteni su natrag u Hrvatsku, a mađarske su vlasti u gradu Magyarbóly vlak držale tri tjedna, nakon čega je vraćen na kolodvor u Osijek.

26 www.net.hr (2020) https://net.hr/danas/hrvatska/zasto-je-milanovic-optuzio-kolindu-da-je-s-petrovom-izvela-operetnidrzavni-udar-evo-sto-se-dogadalo-oko-bozica-2015-godine/ (pristupljeno: 3. 3. 2020.) 
Posljednju repliku vezanu za problem masovnih migracija iskoristila je Kolinda Grabar-Kitarović:

"Treba se ponašati u skladu sa zakonodavstvom, ne možemo izazivati ratove među državama. To je riješeno mojim prijedlogom 2016. godine, kada su Hrvatskom prolazili, ne žene i djeca, nego većinom muškarci, preko 80 \%, koji su bili sposobni i koju su imali mogućnost prelaska, da vojska jednostavno na zahtjev policije eventualno stupi u pomoć. Ne treba ona stati na granice, međutim ima puno tehničke opreme koju može koristiti." (Grabar-Kitarović, 2019)

K. Grabar-Kitarović ukazuje na vlastite zasluge u okviru usvajanja zakonskih promjena vezanih za pojačan nadzor granica. Kao kontrast zakonodavstvu, poziva se na ratove čime implicira na loše odnose Milanovića s političkim liderima susjednih država. Također je bitno istaknuti opovrgavanje Milanovića koji je ranije isticao kako su polovicu ukupnog broja migranata činile žene i djeca. S druge strane, Grabar-Kitarović navodi kako je kroz Hrvatsku zapravo prošlo preko 80 \% muškaraca koji su bili sposobni i koju su imali mogućnost prelaska. Bojazan od povratka iskusnih boraca s istočnih ratišta i njihova infiltracija u zemlje zapadne Europe kroz nekontroliran priljev migranta postao je bitan dio političkog diskursa u državama Europske unije i svojevrstan instrument sekuritizacije migracija. Naglašavajući kako su većina migranata muškarci, K. Grabar-Kitarović implicitno ukazuje na borbeno sposobne osobe, odnosno osobe spremne na počinjenje terorističkih djela. Također, koristi posvojnu zamjenicu mojim kako bi ponovno naglasila kako je upravno ona zaslužna za promjene zakona koje omogućuju izlazak vojske na granice. K. Grabar-Kitarović u ovoj replici ublažava retoriku navodeći kako vojska ipak ne treba stati na granice, nego može pomoći u pogledu tehnologije koja se koristi za nadzor granica.

\subsection{Drugo sučeljavanje u organizaciji Hrvatske radiotelevizije (održano 2. siječnja 2020. godine) - kritička analiza diskursa}

Drugo televizijsko sučeljavanje na HRT-u privuklo je najveću pažnju gledatelja, naime prema podacima kompanije AGB Nielsen, sučeljavanje je pratilo gotovo milijun gledatelja ${ }^{27}$. Iako voditelji sučeljavanja nisu izravno postavljali pitanja vezana za problem masovnih migracija, predsjednički kandidati su u kontekstu pitanja vezanog za odnose Hrvatske sa susjednim zemljama u regiji raspravljali i o migracijskoj krizi iz 2015./2016. godine.

Milanović je ponovno stao u obranu primjene humanitarnog pristupa tijekom migracijske krize iz 2015./2016. godine:

"Što se tiče žilet-žice, ova je teza ponavljanja, razmislite, da nismo djelovali kako smo djelovali, brzo, ljude smo prebacili na Zapad. Znate gdje bi bila žilet-žica? Ti ljudi bi ostali u Hrvatskoj. To su tražili od nas. Zato je žilet-žica, jer smo bili dovoljno brzi da ljude prebacimo u Njemačku." (Milanović, 2020)

U ovoj izjavi Milanović zastupa slične stavove koje je prezentirao na prethodnim televizijskim sučeljavanjima. Ponovno migrante naziva ljudi, izbjegavajući tako bilo kakve izraze kojima se migranti uokvirvaju kao sigurnosna prijetnja. Ponovno naglašava brzinu u prebacivanju migranata na Zapad implicirajući kako je Hrvatska tranzitna zemlja koja nije u interesu migranata kao konačno odredište i stoga migranti ne predstavljaju sigurnosnu prijetnju. Milanović i ovdje koristi retoričko pitanje kako bi naglasio zabrinutost oko eventualnog zadržavanja migranata na teritoriju Hrvatske, nakon

27 www.vecernji.hr (2020) https://www.vecernji.hr/vijesti/predsjednicki-duel-na-htv-u-gledalo-139-gledatelja-1370181 (pristupljeno: 22. 2. 2020.) 
čega ističe vlastitu sposobnost u vođenju vanjske politike u kontekstu „nadmudrivanja“ onih koji su tražili da dio migranata ostane u Hrvatskoj. Milanović ne imenuje osobu, državu ili instituciju koja je tražila od Hrvatske zadržavanje migranata, no u ranijim izjavama u televizijskim sučeljavanjima $\mathrm{u}$ tom je kontekstu često spominjao Angelu Merkel, na koju vjerojatno i ovdje misli.

Replika Kolinde Grabar-Kitarović i ovdje se uglavnom temelji na kritici politike koju je vodio Zoran Milanović kao tadašnji premijer:

"Gospodine Milanoviću, niste ih niti trebali primati u Hrvatsku, da prelaze ilegalno kao što sam to vidjela. Legalni prijelazi su bili otvoreni. Vi ste ih zatvorili sa Srbijom u jednom trenutku i izazvali incident. Svatko ima pravo zatražiti azil. Međutim, vrlo malo ljudi je zatražilo azil u Hrvatskoj, ostali su išli prema Mađarskoj i Sloveniji. Imam dobre odnose s obje države, i jedni i drugi su rekli da ste ih prevarili." (Grabar-Kitarović, 2020)

Grabar-Kitarović i u ovoj replici polarizira pojmove „legalno“ vs. „ilegalno“. Migrante u prvoj rečenici ne imenuje, nego koristi zamjenicu $i h$. Ovdje se ponovno koristi mehanizmom jezične manipulacije polarizirajući nas i njih. Grabar-Kitarović komunicira s pozicije moći, s jedne strane kritizirajući Milanovića za narušavanje odnosa sa susjednim zemljama, a s druge strane ističe sebe kao aktualnu predsjednicu koja održava dobre odnose sa susjednim zemljama. Također, poziva se na incident ${ }^{28}$ koji se zbio sa Srbijom, čime diskreditira prethodnu Milanovićevu izjavu u kojoj je sebe predstavio kao uspješnog i efikasnog premijera u rješavanju problema vezanih za migracijsku krizu ${ }^{29}$. Na kraju izjave, K. Grabar-Kitarović koristi se glasinama navodeći kako su iz Slovenije i Mađarske rekli kako ih je Milanović prevario. Naime, ovdje se radi o neprovjerenim glasinama, što je jedan od elemenata prljave kampanje koja je učinkovita kod odvlačenja pažnje s važnih problema o kojima se raspravlja tijekom izborne kampanje (Vaccari i Morini, 2014, str. 21).

Zoran Milanović u narednoj replici zaoštrava retoriku, i za razliku od prethodnih izjava u kojima je naglašavao kako za vrijeme migracijske krize iz 2015./2016. nije bilo razloga za zabrinutost, ovdje opravdava svoje postupke i pravi zaokret navodeći kako je stanje ipak bilo ozbiljno:

"Cijena je bila da ljudi ostanu u Hrvatskoj, 658 tisuća ljudi odjednom. Bio je pritisak da se zaustavi ta rijeka, jer smo ljude transportirali u Mađarsku i Sloveniju (...) Prema tome, ponovno bih tako postupio, da izbjegnem da Hrvatska bude hotspot. (...) Žilet-žica je posljedica nečega što je moralo biti napravljeno, međutim cijena je bila da ljudi ostanu u Hrvatskoj. Zaustaviti 650 tisuća ljudi potpuno je nemoguće." (Milanović, 2020)

Milanović ponovno koristi brojeve koji se u političkom diskursu najčešće koriste kao sredstvo uokvirivanja migranata u kontekstu prijetnje domaćoj ekonomiji, slabljenja postojećih institucija i struktura moći, ugrožavanja kulturnog identiteta i socijalne kohezije unutar zemlje koja predstavlja konačno odredište (Bali, 2008, str. 471; Huysmans 2000, str. 47-48). Iako Hrvatska, kao tranzitna zemlja, nije konačno odredište migranata, Milanović napominje kako je mogla postati hot-spot (svojevrsni prihvatni centar), što je njegovom brzom reakcijom izbjegnuto. Kako bi dodatno istaknuo

28 Srbija je 2015. godine migrante preusmjerila prema Hrvatskoj, zbog čega je došlo do tenzija između te dvije zemlje. Hrvatska je optuživala Srbiju kako šalje prevelik broj migranata na dnevnoj razini, za što ne postoje kapaciteti. Hrvatska je 20. rujna 2015. godine zatvorila sve granične prijelaze sa Srbijom, uključujući i obustavu teretnog prometa zbog čega su u Srbiji nastale kilometarske kolone kamiona. Srbija je uzvratila zatvaranjem granica za robu koja se uvozi iz Hrvatske, a Hrvatska je na to reagirala potpunim zatvaranjem granica za srbijanske građane i automobile srbijanskih registracijskih oznaka.

29 www.jutarnji.hr (2016) https://www.jutarnji.hr/vijesti/hrvatska/kako-se-odvijala-migrantska-kriza-na-pocetku-su-izbjeglicebile-prihvacene-otvorenih-ruku-a-sada-se-zatvara-ruta-kojom-je-proslo-800.000-ljudi/29593/ (pristupljeno: 30. 8. 2019.) 
vlastite kvalitete i pravovremenu reakciju za vrijeme migracijske krize, Milanović se koristi snažnom metaforom, uspoređujući migrante s rijekom. Metafore se najčešće definiraju kao stilska figura kojom se značenje jedne riječi zamjenjuje značenjem druge (Cunningham-Parmeter, 2001, str. 1551), a u komunikaciji su posebno važne jer reflektiraju, izražavaju i pojačavaju različite načine razumijevanja naših života (Semino, Demjén, Demmen, 2018, str. 625). Korištenjem metafora poput rijeka, poplava, invazija, politički akteri predstavljaju migracije kao sigurnosnu ugrozu, čime izbjegavaju korištenje kompleksnijih argumenata u slučaju uvođenja izvanrednih mjera (Huysmans 2000, str. 48).

\section{Rezultati istraživanja (usporedba stavova predsjedničkih kandidata)}

Provedeno empirijsko istraživanje imalo je za cilj pokazati na koji su način predsjednički kandidati Kolinda Grabar-Kitarović i Zoran Milanović formulirali vlastite stavove vezane za problem nekontroliranog priljeva migranata. Preciznije, metodom kritičke analize diskursa istraženo je jesu li predsjednički kandidati predstavljali masovne migracije kao sigurnosnu prijetnju i koje su razlike u njihovim stavovima. Analizirane su sve izjave (ukupno 53 rečenice) koje su kandidati izložili na tri različita televizijska sučeljavanja, a koje su usko vezane za stavove o problemu masovnog priljeva migranata. Istraživanjem je utvrđeno kako su K. Grabar-Kitarović i Z. Milanović uglavnom koristili elemente negativne kampanje kojima su isticane negativne osobine suparnika ili suparničke politike, odnosno, argumentacija predsjedničkih kandidata uglavnom se temeljila na kritici suparničke politike i događaja vezanih za razdoblje migracijske krize iz 2015./2016. godine. Međutim, iz prezentiranih izjava oko pristupa u rješavanju migracijske krize, moguće je iščitati njihove stavove o migrantima kao sigurnosnoj ugrozi.

\section{Kolinda Grabar-Kitarović}

Kolinda Grabar-Kitarović u svojim je stavovima oštro kritizirala politiku Zorana Milanovića kao bivšeg premijera, označavajući ga kao glavnog krivca za totalni kaos koji je nastao u Republici Hrvatskoj, pogotovo zbog propuštanja migranata za vrijeme migracijske krize iz 2015./2016. godine. Često dijeli prave azilante, od ilegalnih, odnosno ekonomskih migranata čime jasno ukazuje na nepoželjnost svih onih migranata koji nisu pravi azilanti, prema kojima, s druge strane, izražava suosjećanje. Osim navedenih pojmova, K. Grabar-Kitarović polarizira pojmove „ilegalno“ vs. „legalno“, „ja“ vs. „oni“, „nas“ vs. „njih“, što je indikator korištenja jezika manipulacije kojim iregularne migrante označava kao tuđince koji nisu dobrodošli u Republici Hrvatskoj. S druge strane, kod građana Republike Hrvatske želi stvoriti osjećaj pripadnosti kroz iluziju o jednakosti u zajedničkim ciljevima i interesima vezanih za zaštitu granice. Uz to, K. Grabar-Kitarović ističe kako više od 80 \% migranata čine sposobni muškarci, čime implicitno ukazuje na borbeno sposobne osobe, odnosno osobe spremne na počinjenje terorističkih djela. Promatranje migranata kroz okvire terorizma svojstven je diskursu sekuritizirajućih aktera iz zemalja Višegradske skupine koje su sekuritizirale migracije postavljanjem fizičkih barijera na granice i odbijajući uvođenje sustava kvota za raspored izbjeglica, kao i kvota za premještanje tražitelja azila među državama članicama EU-a ${ }^{30}$. Često komunicira s pozicije moći, navodeći kako je upravo ona, kao vrhovna zapovjednica Oružanih snaga, zaslužna za izmjene zakona kojima je vojsci omogućeno pružanje potpore policiji u zaštiti državne granice koja je ugrožena zbog milijuna migranata koji žele krenuti prema Europi.

K. Grabar-Kitarović ističe važnost bilateralnih sastanaka s političkim čelnicima susjednih država i s turskim predsjednikom Erdoğanom, koji, kako navodi, trenutno drži kontrolu nad milijunima migranata i izbjeglica. Predstavljajući Erdoğana kao autoritet, K. Grabar-Kitarović daje značaj

30 Višegradska skupina ili V4 naziv je političke zajednice četiri srednjoeurope države: Mađarske, Slovačke, Češke i Poljske. Skupina je utemeljena 15. veljače 1991. godine u Višegradu, a od 1. svibnja 2004. godine sve su četiri države postale članicama EU. 
vlastitim nastojanjima u sprječavanju ponovnog izbijanja migracijske krize. Također, svoje stavove o vođenju vanjske politike temelji na Milanovićevoj kritici zbog narušavanja odnosa sa susjednim zemljama koje je kasnije vlastitim naporima nastojala popraviti. Za fizičke barijere na granicama s Mađarskom i Slovenijom također optužuje Milanovića navodeći kako je žilet-žica ostavština njegove loše politike koju je vodio prema susjednim zemljama.

Predstavljajući Hrvatsku kao „štit“ i „prvu granicu obrane“ Europske unije od migranata i koristeći sličan diskurs kojeg je koristila politička elita u članicama EU-a koje su sekuritizirale migracije uvođenjem izvanrednih mjera, K. Grabar-Kitarović iregularne migracije predstavlja kao sigurnosnu ugrozu, dok su ugroženi referentni objekti individualna sigurnost građana Hrvatske i Europske unije. Međutim, svoju je retoriku nastojala ublažiti argumentima o otvorenosti granice za sve osobe koje žele zatražiti azil u Hrvatskoj te argumentima kako vojska ipak ne treba stati na granice, nego može pomoći u pogledu primjene tehnologije kojom se vrši nadzor granice.

\section{Zoran Milanović}

Milanović je zauzeo poziciju s koje je branio primjenu humanitarnog pristupa u rješavanju nekontroliranog priljeva migranata iz 2015. godine. Iz provedene kritičke analize diskursa može se zaključiti kako je, za razliku od K. Grabar-Kitarović, koristio jezik kojim je desekuritizirao migracije. Primjerice, u svim sučeljavanjima migrante naziva ljudi, jadni ljudi i ljudska bića, čime izražava suosjećanje prema migrantima, izbjegavajući bilo kakve termine kojima se migranti označavaju kao sigurnosna prijetnja. Dok Grabar-Kitarović tvrdi kako preko 80 \% migranata čine muškarci, Milanović navodi kako je kroz Hrvatsku od ukupnog broja migranata, prošlo pola žena i djece. Iako ne postoji točan podatak koliki je ukupan broj žena, djece ili muškaraca koji su prošli kroz Hrvatsku, preciznost tvrdnji predsjedničkih kandidata ovdje nije relevantna budući da se radi o indikativnom manipuliranju s činjenicama s ciljem sekuritizacije, odnosno desekuritizacije migranata.

Pokazalo se kako Milanović također koristi jezik manipulacije, polarizirajući pojmove „ja“ $v s$. „oni“. Uz predstavljanje sebe u pozitivnom kontekstu, Milanović se polarizacijom ne distancira od migranata, nego od HDZ-a i Kolinde Grabar-Kitarović koju je kritizirao zbog bilateralnih sastanaka s Viktorom Orbánom, Aleksandrom Vučićem i Erdoğanom, koje je označavao kao „negativce ${ }^{\text {“31. }}$. Zbog činjenice kako debatira s aktualnom predsjednicom Kolindom Grabar-Kitarović, Milanović je nastojao uspostaviti dominaciju pozivajući se na veliko iskustvo koje je stekao kao premijer. Također, postavljanjem retoričkih pitanja izražava zabrinutost zbog mogućnosti slanja vojske na granice, ističući kako je vojska ubojna sila koja nema što raditi na granici, čime ponovno nastoji desekuritizirati migracije i diskreditirati K. Grabar-Kitarović zbog donošenja već spomenutih izmjena i dopuna zakona.

Iz provedene kritičke analize diskursa možemo zaključiti kako je Z. Milanović, za razliku od K. Grabar-Kitarović, zauzeo znatno umjereniji stav u vezi sekuritizacije migracija. Migracije ne promatra kao sigurnosnu ugrozu, štoviše, desekuritizira ih i pokazuje suosjećanje prema migrantima. Međutim, kao što K. Grabar-Kitarović u nekoliko navrata ublažava retoriku navodeći kako ne dopušta vrijeđanje migranata, kako je Hrvatska otvorena za svakoga tko hoće zatražiti azil i kako vojska ne treba stati na granice, nego pružiti tehničku pomoć, Milanović dijametralno suprotno zaoštrava retoriku navodeći kako je lukav političar koji je imao plan B i metak u cijevi, a migrante uspoređuje s rijekom, odnosno koristi snažnu metaforu kojom političari često nastoje sekuritizirati migracije.

31 Često je kritizirao Vučićevu politiku, kako za vrijeme premijerskog mandata, tako i u kampanji za predsjedničke izbore 2019./2020. godine. K. Grabar-Kitarović povezivao je s Orbánom, kojeg pejorativno naziva malim diktatorom i koji je naišao na veliku kritiku međunarodne zajednice zbog sekuritizacije migracija. Milanović spominje i Erdoğana čiju moć nad pitanjem migranata opovrgava s ciljem diskreditiranja Kolinde Grabar-Kitarović kao trenutne predsjednice. 
Tako možemo zaključiti kako je kao premijer, u određenim okolnostima, Milanović bio spreman uvesti izvanredne mjere i sekuritizirati migracije, odnosno kako kao eventualni budući predsjednik, mogućnost sekuritizacije migracija ostavlja otvorenom.

\section{Zaključna razmatranja}

Zapadne zemlje su desekuritizirale većinu pitanja koja su bila na tradicionalnoj agendi do kraja hladnog rata, ali su usvojile novu sigurnosnu agendu koja se uglavnom fokusira na probleme vezane za identitet i migracije (Wæver, 1993 prema Buzan, Wæver, 2003). Nekoliko godina nakon vrhunca takozvane migracijske krize iz 2015./2016. godine, ovaj oblik nevojne prijetnje, koji je posebno zahvatio zemlje zapadne Europe, nije nestao. Porast kriminala u državama koje su konačno odredište i strah kako će se preko migranata infiltrirati teroristi, preduvjet su za provođenje izvanrednih mjera u kontekstu sekuritizacije migracija. S druge strane, upravo zbog provođenja sekuritizacije i uvođenja izvanrednih mjera, migracije postaju sigurnosna prijetnja i za same migrante koji često gube živote u Sredozemnom moru ili postaju žrtve trgovine ljudima. Migracijska kriza iz 2015./2016. godine stoga je s razlogom postala jedna od glavnih tema političke debate na nacionalnoj i nadnacionalnoj razini unutar granica Europske unije.

Predsjednički izbori u Hrvatskoj završeni su u siječnju 2020. godine, a već u veljači iste godine turski predsjednik Erdoğan krši uvjete Izjave EU i Turske iz 2016. godine i prema Europi propušta nekoliko tisuća migranata zbog nezadovoljstva oko financijske pomoći EU i tenzija s Ruskom Federacijom koja u Siriji otežava ostvarenje turskih političkih ciljeva u konfliktu sa sirijskim vladinim snagama. Rasprava oko problema migracija tijekom izborne kampanje za predsjednika Republike Hrvatske pokazala se opravdanom, pogotovo zbog uloge Predsjednika u procesu rješavanja sigurnosnih izazova koje donose masovne migracije.

U ovom su radu analizirani stavovi predsjedničkih kandidata Zorana Milanovića i Kolinde GrabarKitarović, a istraživanje je imalo za cilj odgovoriti na pitanja: jesu li predsjednički kandidati predstavljali migracije kao sigurnosnu ugrozu i koje su razlike u njihovim stavovima vezanim za sigurnosne izazove koje donose masovne migracije. Kritičkom analizom diskursa pokazalo se kako je Kolinda Grabar-Kitarović koristila sigurnosni diskurs svojstven političkim akterima koji imaju za cilj sekuritizirati migracije. Migrante je često, implicitno i eksplicitno, označavala kao sigurnosnu ugrozu, a Hrvatsku i EU označava kao ugrožena društva, odnosno referentne objekte koje treba zaštiti od iregularnih migranata. Kolinda Grabar-Kitarović koristi sigurnosne okvire u kojima se migrante obično povezuje s terorizmom i kriminalom. S druge strane, Zoran Milanović koristi jezik kojim desekuritizira migracije, prikazujući migrante kao ugroženu populaciju kojoj je potrebna pomoć. Međutim, istraživanjem je utvrđeno kako je Milanović, mogućnost sekuritizacije migracija u Republici Hrvatskoj ostavio otvorenom, pogotovo zbog mogućih migracijskih tokova uzrokovanih različitim push i pull faktorima u nefunkcionalnim državama Bliskog istoka i sjeverne Afrike. 


\section{Literatura}

Athanasiadou, A. (1991). The discourse function of questions, Pragmatics, 1(1), 107-122.

Bigo, D. (2002). Security and Immigration: Toward a Critique of the Governmentality of Unease. Alternatives, 27(1), 63-92.

Böhmelt, T. i Bove, V. (2015). Does Immigration Induce Terrorism?. Journal of Politics, 78(2), 1-37.

Buzan, B. i Wæver, O. (2003). Regions and Powers: The Structure of International Security.

Cambridge University Press.

Buzan, B., Wæver, O. i de Wilde, J. (1998). Security: A New Framework For Analysis. Lynne Rienner Publishers.

Car, V. i Vrtič, I. (2016). Manipulacija u medijskom diskursu: kritička analiza diskursa naslova najposjećenijih hrvatskih online medija o hrvatskoj predsjednici Kolindi Grabar Kitarović. U: V. Car, M. Matović, L. Turčilo (ur.), Mediji i javni interes (str. 145-167). FPZG; Hanns-Siedel-Stifung. Cunningham-Parmeter, K. (2011). Alien Language: Immigration Metaphors and the Jurisprudence of Otherness. Fordham Law Review, 79(4), 1545-1598.

Edelman, M. (2003). Konstrukcija političkog spektakla. Politička kultura.

Elias, N. i Scotson, J. (1994). The Established and The Outsiders: A Sociological Enquiry into Community Problems. Sage.

Emmers, R. (2010). Sekuritizacija. U: A. Collins (ur.), Suvremene sigurnosne studije (str. 133-150). Centar za međunarodne i sigurnosne studije Fakulteta političkih znanosti Sveučilišta u Zagrebu Politička kultura.

Fairclough, N. (1992). Discourse and Social Change. Polity Press.

Fairclough, N. (1993). Critical discourse analysis and the marketization of public discourse: the universities. Discourse Society 4, 133-68.

Fairclough, N. (1995). Media Discourse. Norman.

Fairclough, N. (2003). Analysing Discourse - Textual analysis for social research. Routledge.

Fairclough, N. (2005). Analysing Discourse - Textual analysis for social research. Routledge.

Fischer-Lichte i E., Pflug, I. (2000). Inszenierung von Authentizität. Francke.

Foucault, M. (1972). The Archaeology of Knowledge. A. M. Tavistock.

Furedi, F. (2007). The only thing we have to fear is the culture of fear itself. Spiked, http://frankfuredi. com/pdf/fearssay-20070404.pdf.

Grbeša, M. (2008). Personality politics in Croatia: An inquiry into election campaigns, media coverage and public perception in the 2003 and 2007 parliamentary elections. Doktorska disertacija. Fakulteta za družbene vede - Ljubljana.

Harašić, Ž. (2015). Autoritet i sud. Zbornik radova Pravnog fakulteta u Splitu, 52(2), 407-429.

Huysmans, J. (2000). The European Union and the Securitizaion of Migration. Journal of Common Market Studies, 38(5), 751-777.

Huysmans, J. (2006). The Politics of Insecurity. Fear, Migration and Asylum in the EU. Routledge.

Iosifides, T. (2018). Epistemological Issues in Qualitative Migration Research: Self-Reflexivity, Objectivity and Subjectivity. U: R. Zapata-Barrero, E. Yalaz (ur.), Qualitative Research in European 
Migration Studies (str. 93-113), IMISCOE Research Series. Springer.

Jakešević, R. i Tatalović, S. (2016). Securitization (And De-Securitization) of the European Refugee Crisis: Croatia in the Regional Context. Teorija in praksa 53(5), 1246-1264.

Jarman, J. W. (2018). It Wasn't Even Close: Viewers' Thoughts about the First 2012 Presidental Debate, U: E. Hinck, E. (ur.), Televised Presidential Debates in a Changing Media Environment (str. 165-185).

Karlsson, S. (2018). A Critical Discourse Analysis of the Race Segment of Clinton's and Trumps' first Presidential Debate. Independent thesis Basic level. Mid Sweden University, Faculty of Human Sciences, Department of Humanities.

Kolodziej, A. E. (2011). Sigurnost i međunarodni odnosi. Politička kultura.

Lalić, D. i Kunac, S. (2010). Izborne kampanje u Hrvatskoj. Politička misao.

Lalić, D. (2004). Obilježja pakiranja politike u izbornoj kampanji HDZ-a i SDP-a 2003. godine. Politička misao, 41(1), 55-73.

Lindquist, P. (2017). Welcome to the new jungle: A discourse analysis of the securitization of migration in the Calais crisis in British media. Master Thesis in Global Studies. University of Gothenburg.

Maldini, P. i Takahashi, M. (2017). Refugee Crisis and the European Union: Do the Failed Migration and Asylum Policies Indicate a Political and Structural Crisis of European Integration?, Communication Management Review, 2(2), 54-72.

McNair, B. (2003). Uvod u političku komunikaciju. Politička misao.

Mehan, H. (1997). The discourse of the illegal immigration debate: a case study in the politics of representation. Discourse \& Society, 8(2), 249-270.

Meyer, T. (2003). Mediokracija: Medijska kolonizacija politike. Fakultet političkih znanosti Sveučilišta u Zagrebu.

Mills, S. (1997). Discourse. Routledge.

Onuf, N. (1998). Constructivism: A User's Manual. U: V. Lubalkova, N. Onuf, P. Kowert (ur.), International Relations in a Constructed World. M. E. Sharpe.

Peruško, Z. i Vozab, D. (2018). Izvori informiranja o politici kao moderatori postizbornih očekivanja građana: parlamentarni izbori 2016., Zagreb: Društvena istraživanja (časopis za opća društvena pitanja), 27(3), 453-472.

Podboj, M. (2011). Manipulacija u političkom diskursu - kritički pristup. Hrvatistika, 5(5), 123-133.

Pravni leksikon (2007). Leksikografski zavod Miroslav Krleža.

Ristić, D. (2015). Značenja delanja: sociološka analiza diskurzivnih praksi ideologije. Doktorska disertacija. Filozofski fakultet - Novi Sad.

Semino, E., Demjén, Z. i Demmen, J. (2018). An Integrated Approach to Metaphor and Framing in Cognition, Discourse, and Practice, with an Application to Metaphors for Cancer. Applied Linguistics, 39(5), 625-645.

Skoko, B. (2005). Uloga televizijskih sučeljavanja u predizbornoj kampanji za predsjedničke izbore: hrvatska iskustva 2005. Politička misao, 42(1), 61-83.

Street, J. (2003). Masovni mediji, politika i demokracija. Fakultet političkih znanosti. 
Szalai, A. (2017). Securitization as Enacted Melodrama: The Political Spectacle of the Hungarian Anti-Immigration Campaign, ECPR General Conference 2017, University of Oslo, Panel: Studying the Meaning(s) of Politics: Theoretical Perspectives.

Szalai, A. i Gőbl, G. (2015). Securitizing Migration in Contemporary Hungary, Working Paper. Centre for EU Enlargement Studies.

Šiber, I. (2003). Politički marketing. Politička kultura.

Vaccari, C. i Morini, M. (2014). The Power of Smears in Two American Presidental Campaigns, Journal of Political Marketing, 13(1), 19-45.

Van Dijk T. A. (2018). Discourse and Migration. U: R. Zapata-Barrero, E. Yalaz (ur.), Qualitative Research in European Migration Studies (str. 227-247), IMISCOE Research Series. Springer.

Vezovnik, A. (2017). Securitizing Migration in Slovenia: A Discourse Analysis of the Slovenian Refugee Situation. Journal of Immigrant \& Refugee Studies, 16(1-2), 39-56.

Watson, S. (2009). The Securitisation of Humanitarian Migration: Digging moats and sinking boats. Routledge.

Bali, S. (2008). Population movements, U: D. P. Williams (ur.), Security Studies: An Introduction. Routledge.

Wolfers, A. (1952). „Natioanl Security“ as an Ambiguous Symbol, The Academy of Political Science, Political Science Quarterly, 67(4), 481-502.

Zakon o nadzoru državne granice NN 83/13 (NN 27/16). Preuzeto 7. 2. 2020. https://www.zakon. $\mathrm{hr} / \mathrm{z} / 450 /$ Zakon-o-nadzoru-dr\%C5\%BEavne-granice

Zakon o obrani NN 73/13 (NN 30/18). Preuzeto 7. 2. 2020. https://www.zakon.hr/z/334/Zakon-o-obrani Zorko, M. (2018). Geopolitika i teritorijalnost. Naklada Jesenski i Turk.

www.dnevnik.hr (2015) https://dnevnik.hr/vijesti/hrvatska/kolinda-merkel---409544.html (pristupljeno: 20. 2. 2020.)

www.izbori.hr (2019) https://www.izbori.hr/pre2019/rezultati/1/ (pristupljeno: 7. 1. 2020.) www.večernji.hr (2020) https://www.vecernji.hr/premium/kolika-je-stvarna-moc-vladarapantovcaka-milanovic-ima-cak-188-ovlasti-1379522 (pristupljeno: 16. 2. 2020.)

www.jutarnji.hr (2016) https://www.jutarnji.hr/vijesti/hrvatska/na-sjednici-vlade-usvojen-novizakon-vojska-moze-na-granicu-merkel-odusevila-premijera-sastanak-je-bio-sjajan/27514/ (pristupljeno: 14. 11.2018.)

ec.europa.eu (2019) https://ec.europa.eu/commfrontoffice/publicopinion/index.cfm/Survey/ getSurveyDetail/instruments/standard/yearFrom/2018/yearTo/2020/surveyKy/2255 (pristupljeno: 11. 2. 2020.)

www.frontex.europa.eu (2017) https://frontex.europa.eu/along-eu-borders/migratory-routes/ western-balkan-route/ (pristupljeno: 21. 1. 2020.)

www.index.hr (2017) https://www.index.hr/vijesti/clanak/hrvatska-dobila-novu-strategijunacionalne-sigurnosti/982691.aspx (pristupljeno: 11. 01. 2020.)

www.uvns.hr (2020) https://www.uvns.hr/UserDocsImages/dokumenti/nacionalna-sigurnost/ Strategija-nacionalne-sigurnosti-RH.pdf (pristupljeno: 10. 2. 2020.)

www.uvns.hr (2020) https://www.uvns.hr/UserDocsImages/dokumenti/nacionalna-sigurnost/ 
Strategija\%20nacionalne\%20sigurnosti\%20RH.pdf (pristupljeno: 10. 2. 2020.)

www.jutarnji.hr (2016) https://www.jutarnji.hr/vijesti/hrvatska/hrvatski-mup-ima-novi-helikopterza-nadzor-granice-evo-cime-je-sve-opremljen/4479974/ (pristupljeno: 14. 2. 2020.)

www.jutarnji.hr (2016) https://www.jutarnji.hr/vijesti/hrvatska/hrvatska-dobiva-

najmoderniji-sustav-nadzora-stizu-radari-i-kamere-za-schengen-otkrivamo-gdje-ce-sve-biti-

postavljeni/4049031/ (pristupljeno: 14. 2. 2020.)

www.fundforpeace.org (2018) https://fundforpeace.org/fsi/wp-content/

uploads/2018/04/951181805-Fragile-States-Index-Annual-Report-2018.pdf (pristupljeno: 8. 2.

2020.)

www.tportal.hr (2019) https://www.tportal.hr/vijesti/clanak/suceljavanje-predsjednickih-

kandidata-na-hrt-u-gledalo-gotovo-700-000-ljudi-20191218 (pristupljeno: 19. 2. 2020.)

www.net.hr (2019) https://net.hr/danas/hrvatska/rtl-je-debatom-oborio-rekord-prvo-suceljavanjekolinde-i-milanovica-gledalo-je-vise-od-milijun-gledatelja/ (pristupljeno: 22. 2. 2020.)

www.vecernji.hr (2020) https://www.vecernji.hr/vijesti/predsjednicki-duel-na-htv-u-gledalo-139gledatelja-1370181 (pristupljeno: 22. 2. 2020.)

www.dnevnik.hr (2020) https://novatv.dnevnik.hr/clanak/zanimljivosti/gledatelji-ponovnoodabrali-novu-tv---589382.html (pristupljeno: 22. 2. 2020.)

www.net.hr (2020) https://net.hr/danas/hrvatska/zasto-je-milanovic-optuzio-kolindu-daje-s-petrovom-izvela-operetni-drzavni-udar-evo-sto-se-dogadalo-oko-bozica-2015-godine/ (pristupljeno: 3. 3. 2020.)

www.vecernji.hr (2020) https://www.vecernji.hr/vijesti/predsjednicki-duel-na-htv-u-gledalo-139gledatelja-1370181 (pristupljeno: 22. 2. 2020.)

www.jutarnji.hr (2016) https://www.jutarnji.hr/vijesti/hrvatska/kako-se-odvijala-migrantska-krizana-pocetku-su-izbjeglice-bile-prihvacene-otvorenih-ruku-a-sada-se-zatvara-ruta-kojom-je-proslo800.000-ljudi/29593/ (pristupljeno: 30. 2. 2020.) 


\section{Securitization of irregular migration in the $2019 / 2020$ presidential election campaign in the Republic of Croatia.}

\section{GORAN DŽIDIĆ}

PhD Candidate

Faculty of Political Science, University of Zagreb

dzidic.goran@gmail.com

A few years after the peak of the 2015 migration crisis, this type of nonmilitary threat has become an important part of the political debate at national and supranational level of the European Union. The Republic of Croatia, as a part of the so-called Balkan Route, is no exception. Migration crisis from the 2015/2016 represents one of the most important issues discussed during the 2019/2020 presidential election campaign in the Republic of Croatia. Applying critical discourse analysis, this paper aims to explore the views of presidential candidates Zoran Milanović and Kolinda Grabar-Kitarović regarding the security challenges caused by mass migration. Units of analysis are the statements of the presidential candidates presented at the three television debates held during the presidential election campaign.

Keywords: securitization, irregular migration, critical discourse analysis, presidential elections, Republic of Croatia, European Union 